DOI: 10.17707/AgricultForest.64.3.03

\author{
Khemais ABDELLAOUI, Fatma ACHEUK, \\ Meriem MILADI, Iteb BOUGHATTAS, Ghofrane OMRI ${ }^{1}$
}

\title{
PHYTOCHEMISTRY, BIOCHEMICAL AND INSECTICIDAL ACTIVITIES OF RUTA CHALEPENSIS ESSENTIAL OILS ON TRIBOLIUM CONFUSUM
}

SUMMARY
The confused flour beetle, Tribolium confusum (Coleoptera: Tenebrionidae) is a common pest insect known for attacking and infesting stored flour and grain. Biodegradable and ecologically natural products such as essential oils are emerging candidates for replacement of usually applied chemical pesticides. The essential oils of Ruta chalepensis flowering aerial parts were investigated for their contact toxicity and physiological aspects on T. confusum.

Essential oils were obtained by hydrodistillation and 56 components were identified by GC-MS. Our results clearly indicated that these compounds exhibited toxicity against $T$. confusum pupae and adults with an $\mathrm{LC}_{50}$ value of 0.08 and $0.055 \mu \mathrm{L} / \mathrm{cm}^{2}$, respectively after 7 days of treatment. In repellency assay, essential oils repelled $T$. confusum adults significantly even at $0.06 \mu \mathrm{L} / \mathrm{cm}^{2}$ concentration in an area preference test. Result also showed that maximum exposure time resulted in maximum repellency of the pest at all the concentrations. The repellent activity could be related to the abundance of the 2undecanone (25.94\%) in the oils. In other experiments, the essential oils were investigated on the activities of acetylcholinesterase (AChE) and glutathione $S$ transferases (GSTs). Biochemical analysis demonstrated that the essential oils of $R$. chalepensis induced GSTs and reduced the activity of AChE. Based on these results, essential oils of $R$. chalepensis origin could have greater potential in future in stored-product pest management.

Keywords: Essential oils, phytochemistry, toxicity, Acetylcholinesterase, glutathione S-transferases.

\section{INTRODUCTION}

Stored products of agricultural and animal origin are attacked by more than 600 species of beetle pests, 70 species of moths and about 355 species of mites causing quantitative and qualitative losses (Rajendran and Sriranjini, 2008).

\footnotetext{
${ }^{1}$ Khemais Abdellaoui (corresponding author: kemais_a@yahoo.fr), Meriem Miladi, Iteb Boughattas, Ghofrane Omri, Department of biological sciences and plants protection, Higher Institute of agronomy, Chott Mariem, Sousse University, TUNISIA; Fatma Acheuk, Laboratory of Valorization and Conservation of Biological Resources”Valcore”, Department of Biology, Faculty of Sciences, University of Boumerdes, Boumerdes, 35000 ALGERIA.

Notes: The authors declare that they have no conflicts of interest. Authorship Form signed online.
} 
Stored-grain insect pests have been damaging food grains in granaries and store houses and accounts for 10-40\% loss worldwide (Chaubey, 2012). The confused flour beetle, Tribolium confusum (Coleoptera: Tenebrionidae) is a very common pest infesting many flour mills, warehouses and grocery stores. It is cosmopolitan and considered one of the major stored-product insects (Garcìa et al., 2005). In Tunisia and North Africa, Jarraya (2003) reported that this insect is amid the most important and destructive pests in mills.

Infestations of stored product insects are typically controlled by the use of synthetic insecticides and fumigants. Currently, phosphine and methyl bromide are the common product worldwide used for stored protection (Suthisut et al., 2011). These insecticides are the most effective applications for the protection of flour mills, grocery shops, warehouses, and other agricultural commodities from stored insect infestation (Park et al., 2004). However, they have a number of associated disadvantages, such as environmental pollution, development of insect resistance and potential toxicity to non target organisms. The use of methyl bromide is being restricted because of its potential to damage the ozone layer (Butler and Rodriguez, 1996; MBTOC, 1998). The Montreal Protocol of the United Nations Environment Program (UNEP 1995) recommends the phasing out of methyl bromide by 2005 in developed countries and by 2015 in developing countries (MBTOC, 1998). Insect resistance to phosphine is a global issue now and control failures have been reported in field situations in some countries (Rajendran and Sriranjini, 2008). Collins et al. (2005) and Pimentel et al. (2009) reported that phosphine is not effective against some insect populations in India, Australia and Brazil, because of resistance. Therefore, today there is a need to develop alternatives that is capable of reducing the large-scale utilization of synthetic pesticides for crop protection.

Research in recent years has been turning more towards selective biorational pesticides. Among these botanical insecticides have attracted the greatest attention and have been reviewed extensively (Abdellaoui et al., 2013). Plants have always been rich source of chemicals and drugs for human and synthesize a wide array of compounds that are generally thought to be involved in plant-insect interactions (Amason et al., 1981). Thus, organic molecules of botanical origin may offer a safe source of compounds for pest management, being environmentally friendly, and an excellent alternative to persistent synthetic insecticides (Abdellaoui et al., 2015).

Among the natural compounds produced by plants, the essential oils appear to directly or indirectly influence the patterns of growth and reproduction of associated phytophagous insects. Essential oils, secondary metabolites that plants produce for their own needs other than for nutrition, have traditionally been utilized to protect stored grain and legumes (Isman, 2000). In recent years, they received a great deal of attention as pest control agents. These complex mixtures, and their individual constituents, have been shown to possess multiple pest control properties, including toxic, repellent, ovicidal, antifeedant and antioviposition effects (Ho et al., 1996; Bakkali et al., 2008; Rajendran and 
Sriranjini, 2008). Liu et al. (2013) reported that many essential oils from plants including medicinal herbs, spices and fruits have been evaluated and shown to be effective as pesticides against stored product insects. In addition, they are low toxic to human and animals, volatile and can function as fumigants, and may also be applicable to the protection of stored products (Sahaf et al., 2008).

In an effort to identify novel active natural products derived from plants as alternatives to conventional insecticides, we have studied the contact toxicity and repellency effect of $R$. chalepensis, medicinal plant which occur in the Tunisia flora, essential oils against $T$. confusum.

\section{MATERIAL AND METHODS}

\section{Insect rearing}

T. confusum was reared in 2-L plastic containers containing wheat flour mixed with yeast $(10: 1 \mathrm{w} / \mathrm{w})$. The cultures were maintained in darkness in a growth chamber set at $30 \pm 1^{\circ} \mathrm{C}$ and $60-70 \%$ r.h.

\section{Plant materials}

Aerial parts of $R$. chalepensis were collected at full-flowering stage during spring season (March-April) from the region of Kairouan (N: 35.67 $\left., \mathrm{E}: 10.09^{\circ}\right)$ in the Center of Tunisia. The samples were dried in the shade at room temperature for two weeks. After drying, the samples were ground to a fine powder used for the extraction of essential oils.

\section{Essential oil extraction and identification}

The essential oils have been extracted from $100 \mathrm{~g}$ air-dried flowering aerial parts of $R$. chalepensis by hydrodistillation for $4 \mathrm{~h}$, using a Clevenger-type apparatus. The essential oils were dried using anhydrous sodium sulphate and then stored in sterile tubes at $4^{\circ} \mathrm{C}$ until analyses.

Chemical components of essential oils were identified with gas chromatography-mass spectrometry instrument (GCMS-QP 2010 Plus Shimadzu, Japan). RTX $-5 \mathrm{~ms}$ capillary column $30 \mathrm{~m} \times 0.25 \mathrm{~mm} \times 0.25 \mu \mathrm{m}$ film thickness was used. The column temperature was initially set at $50^{\circ} \mathrm{C}$ for $2 \mathrm{~min}$, then gradually ramped at $7^{\circ} \mathrm{C} / \mathrm{min}$ to $250^{\circ} \mathrm{C}$ and then left at $250^{\circ} \mathrm{C}$ for $5 \mathrm{~min}$. Injection and detector temperatures were kept respectively at 250 and $280^{\circ} \mathrm{C}$. The carrier gas was helium (99.995\% purity), the flow through the column was $1.2 \mathrm{~mL} / \mathrm{min}$ and the split ratio was set to 1:50 with injection of $1 \mu \mathrm{L}$ of oil sample. The mass spectrometer conditions were as follow: ionization voltage $70 \mathrm{eV}$, ion source temperature $200^{\circ} \mathrm{C}$ and the scan range was from 50 to $550 \mathrm{~m} / \mathrm{z}$. The identification of the components separated by GC-MS was made by comparing the obtained mass spectra for each component with the values stored in NIST Mass Spectral Library (NIST 08). The percentage composition of the oils was calculated in peak areas using the normalization method.

\section{Contact toxicity}

In an effort to determine the toxicity by contact of the $R$. chalepensis essential oils and the median effective time to cause mortality in $50 \%$ of tested insects ( $\mathrm{LT}_{50}$ values), three solutions of essential oils were prepared in acetone. 
$500 \mu \mathrm{L}$ of each solution was applied to the surface of filter papers (Whatman No. 1 , cut into $5 \mathrm{~cm}$ diameter pieces) and homogeneously dispersed, giving a range of concentration of $0.06,0.12$ and $0.25 \mu \mathrm{L} / \mathrm{cm}^{2}$. Controls were treated with solvent alone. The solvent was allowed to evaporate for $10 \mathrm{~min}$ prior to the introduction of $20 \mathrm{~T}$. confusum adults (1-6 days old) or pupae (0-1 day old) selected randomly. In the adult boxes, $0.5 \mathrm{~g}$ of food (artificial diet of wheat flour mixed with beer yeast: $10 / 1 \mathrm{w} / \mathrm{w}$ ) was added. Control and treated groups were kept under the same conditions described above for mass rearing. Each treatment was replicated four times. The mortality was assessed daily via direct observation for a period of 7 days, and when no antennal movements were observed, the insects were considered dead. Probit analysis (Finney, 1971) was conducted to estimate the $\mathrm{LC}_{50}$ and $\mathrm{LC}_{95}$ values with their $95 \%$ confidence limits. Time-mortality data for each experiment were analyzed via the method developed by Finney (1971), with time as the explanatory variable to derive the estimated time for $50 \%$ mortality $\left(\mathrm{LT}_{50}\right)$.

\section{Repellency bioassay}

An area preference method (Zhang et al., 2011) was adopted to assess the repellent activity of $R$. chalepensis essential oils against $T$. confusum adults. Experiments were carried out in glass Petri dishes (diameter $8.5 \mathrm{~cm}$ and height $1.2 \mathrm{~cm}$ ) using concentrations of $0.06,0.12$ and $0.25 \mu \mathrm{L} / \mathrm{cm}^{2}$ prepared in acetone. Whatman filter paper was cut into two equal halves and each test solution (500 $\mu \mathrm{L}$ ) was applied to filter paper half as uniform as possible using micropipette. The other half of filter paper was treated with acetone only as a control. The treated and control half disks were air-dried to evaporate solvent completely. Both treated and untreated halves were then attached with cellophane tape and placed at the bottom in Petri dish. Twenty adults of $T$. confusum (7-10 days old) were released at the centre of each filter paper disk and then Petri dishes were covered, sealed with parafilm and kept in dark. Five replicates were performed for each tested concentration. The number of insects on both treated and untreated halves was recorded after 1,2 and $4 \mathrm{~h}$ of exposure. Percentage repellency (PR) was calculated according to Nerio et al. (2009) as follows: PR = $[(\mathrm{Nc}-\mathrm{Nt}) /(\mathrm{Nc}+\mathrm{Nt})] \times 100$, where Nc was the number of insects on the untreated area and Nt was the number of insects on the treated area.

\section{Enzymatic assays}

Larvae were homogenized in $1 \mathrm{~mL}$ of $0.1 \mathrm{M}$ phosphate buffer ( $\mathrm{pH} 7.4$ ) using a Teflon glass tissue homogenizer. Homogenates were centrifuged $(15,000$ $\mathrm{g}$ for $20 \mathrm{~min}$ at $4^{\circ} \mathrm{C}$ ) and supernatants were used for enzyme assays.

The acetylcholinesterase activity (AChE) was determined according to the method of Ellman et al. (1961) using the Jenway 6105 spectrophotometer. The reaction medium included sodium phosphate buffer (0.1 M, pH 7.2), DTNB (1.6 $\mathrm{mM})$, AcSChI (156 mM) and sample (S9). Kinetics was recorded at $412 \mathrm{~nm}$ and the assay was carried out at $25^{\circ} \mathrm{C}$. The enzymatic activity was expressed as nmol of acetylthiocholine hydrolyzed per min per mg of proteins. 
The glutathione $S$-transferase (GST) activity was measured by the method of Habig et al. (1974) using $10 \mathrm{mg}$ of cytosolic protein, $1 \mathrm{mM}$ 1-chloro- 2,4dinitrobenzene (CDNB) (Sigma-Aldrich, Saint Louis, MO, USA) and $4 \mathrm{mM}$ glutathione (reduced form; GSH) in $100 \mathrm{mM}$ sodium phosphate buffer, $\mathrm{pH}$ substrate 7.5. GST activity was determined by kinetic measurement at $20^{\circ} \mathrm{C}$ using a Jenway 6105 spectrophotometer $(\lambda=340 \mathrm{~nm})$. The results were expressed as nmol GSH-CDNB produced per min and per mg proteins. Proteins in the S9 fraction were quantified according to the Bradford (1976) method using Coomassie Blue reagent.

\section{Data analysis}

Statistical analysis was performed using Probit analysis (Fienny, 1971) to determine $\mathrm{LC}_{50}$ and $\mathrm{LC}_{95}$ values with their 95\% confidence limits. Data from repellency and enzymes activities were expressed as means \pm standard deviation (SD) and subjected to analysis of variance (ANOVA) using Statistical Package for Social Sciences (SPSS: version 18.0). The significance between control and treated series was made by Student-Newman-Keuls (SNK) test at the 5\% level.

\section{RESULTS AND DISCUSSION \\ Chemical composition of essential oils}

The essential oils yield of $R$. chalepensis flowering aerial parts was $0.87 \pm$ $0.05 \%(\mathrm{~V} / \mathrm{W})$ on the basis of dry matter weight. The results of the chemical analysis are shown in Table 1. A total number of 56 components were identified by GC-MS. The main components of $R$. chalepensis essential oils were 2Octanol acetate (30.98\%), 2-Undecanone (25.94\%), 2-Nonanone (16.28\%) and 5-Dodecanone acetate $(9.35 \%)$. Major compounds were followed by others components with lower percentages which are 2-Nonanol (2.54\%) and 2Decanone (2.42\%) (Table 1).

\section{Contact toxicity bioassay}

Contact toxicity after 7 days of treatment was determined. $\mathrm{LC}_{50}$ and $\mathrm{LC}_{95}$ values, and their 95\% confidence limits expressed as microliter per square centimeter are shown in Table 2. The evaluation of contact toxicity data revealed that $R$. chalepensis essential oil was toxic for both pupae and adults of $T$. confusum. Probit analysis showed that $T$. confusum pupae were more susceptible to $R$. chalepensis essential oil than adults. The corresponding $\mathrm{LC}_{50}$ and $\mathrm{LC}_{95}$ values were respectively 0.05 and $0.12 \mu \mathrm{L} / \mathrm{cm}^{2}$ against 0.08 and $0.2 \mu \mathrm{L} / \mathrm{cm}^{2}$ (Table 2). Our experiments also showed that the essential oil of $R$. chalepensis flowering aerial parts exhibited acute toxic effects especially when applied at the two highest concentrations $\left(0.12\right.$ and $\left.0.25 \mu \mathrm{L} / \mathrm{cm}^{2}\right)$.

Bioassay was also designed to determine median effective time to cause mortality of $50 \%$ of treated insects $\left(\mathrm{LT}_{50}\right)$. Considerable differences in $\mathrm{LT}_{50}$ values were noted with different concentrations and developmental stage. Results in Table 3 show that pupae were significantly more susceptible than adults. For pupa stage, $\mathrm{LT}_{50}$ values ranged from 3.75 days for the lowest dose $\left(0.06 \mu \mathrm{L} / \mathrm{cm}^{2}\right)$ 
to 1.04 days for the highest dose $\left(0.25 \mu \mathrm{L} / \mathrm{cm}^{2}\right)$. With adults, the $\mathrm{LT}_{50}$ values ranged from 7.6 days to 1.16 days for the lowest and highest doses, respectively.

Table 1. Chemical constituents of the essential oils from $R$. chalepensis flowering aerial parts collected from Kairouan, Tunisia.

\begin{tabular}{|c|c|c|c|}
\hline No. & Compounds & Retention time & $\%$ \\
\hline 1 & 2-Hexanal, (E)- & 5.135 & 0.18 \\
\hline 2 & $\begin{array}{l}\text { Butanoic acid, 2-methyl-,1-methylethyl } \\
\text { ester }\end{array}$ & 5.873 & 0.16 \\
\hline 3 & 2-Octanone & 8.301 & 0.35 \\
\hline 4 & 2-Octanol, (R)- & 8.524 & 0.12 \\
\hline 5 & 2-Heptanol, acetate & 9.508 & 0.43 \\
\hline 6 & 2-Nonanone & 10.848 & 16.28 \\
\hline 7 & 2-Nonanol & 11.039 & 2.54 \\
\hline 8 & Nonanal & 11.110 & 0.19 \\
\hline 9 & 1,3-Cycloheptadiene & 11.995 & 0.69 \\
\hline 10 & 2-Decanone & 13.053 & 2.42 \\
\hline 11 & 2-Octanol, acetate & 14.133 & 30.98 \\
\hline 12 & 2-Tridecanone & 14.468 & 1.72 \\
\hline 13 & 2-Undecanone & 15.389 & 25.94 \\
\hline 14 & Acetic acid, nonyl ester & 15.596 & 0.13 \\
\hline 15 & 2-Heptanol, acetate & 16.035 & 0.37 \\
\hline 16 & 2-Dodecanone & 16.706 & 1.84 \\
\hline 17 & 5-Dodecanol acetate & 18.034 & 9.35 \\
\hline 18 & Lauryl acetate & 19.278 & 0.16 \\
\hline 19 & (E)-2-Decenyl acetate & 19.893 & 0.39 \\
\hline 20 & 6-Dodecanol acetate & 20.300 & 0.78 \\
\hline 21 & $\begin{array}{l}\text { 4-(3,4-Methylenedioxyphenyl)-2- } \\
\text { butanone }\end{array}$ & 21.238 & 0.28 \\
\hline 22 & $\begin{array}{l}\text { Propanedioic acid, (phenylmethyl)-, } \\
\text { diethyl ester }\end{array}$ & 23.677 & 0.36 \\
\hline 23 & 1, 3-Benzodoxole, 5-propyl- & 24.802 & 0.89 \\
\hline 24 & 1-Adamantaneacetic acid & 28.179 & 0.31 \\
\hline 25 & Phytol & 29.077 & 0.12 \\
\hline 26 & $\begin{array}{l}\text { Pyrrolo [3, 2-g] quinolone, 9-methoxy-2, } \\
\text { 3, 5, 7-tetramethyl- }\end{array}$ & 30.295 & 1.47 \\
\hline $27-56$ & Other components & - & 1.59 \\
\hline $\begin{array}{l}\text { EO } \\
\text { yields } \\
(\%)\end{array}$ & & & $\begin{array}{r}0.87 \\
\pm 0.05\end{array}$ \\
\hline
\end{tabular}


Table 2. Toxicity of $T$. confusum pupae and adults treated with $R$. chalepensis essential oil in contact toxicity bioassay.

\begin{tabular}{cccccc}
\hline Insects & $\mathrm{LC}_{50}{ }^{\mathrm{a}, \mathrm{b}}$ & $\mathrm{LC}_{95}{ }^{\mathrm{a}, \mathrm{b}}$ & $\mathrm{Chi}$ square $(\chi 2)$ & $\mathrm{df}$ & $P$-value \\
\hline Adults & 0.08 & 0.20 & 7.52 & 2 & 0.02 \\
& $(0.01-0.16)$ & $(0.13-0.64)$ & & & \\
\hline Pupae & 0.055 & 0.12 & 6.22 & 2 & 0.04 \\
& $(0.02-0.09)$ & $(0.1-0.29)$ & & & \\
\hline
\end{tabular}

${ }^{\mathrm{a}}$ Units $\mathrm{LC}_{50}$ and $\mathrm{LC}_{95}=\mu \mathrm{L} / \mathrm{cm}^{2}$.

${ }^{\mathrm{b}}$ 95\% lower and upper fiducial limits are shown in parenthesis.

Table 3. $\mathrm{LT}_{50}$ values of $R$. chalepensis essential oil against pupae and adults of T. confusum.

\begin{tabular}{lcccc}
\hline Insects & $\begin{array}{c}\text { Concentration } \\
\left(\mu \mathrm{L} / \mathrm{cm}^{2}\right)\end{array}$ & $\mathrm{LT}_{50}(\text { days })^{\mathrm{a}}$ & $\mathrm{df}$ & $\begin{array}{c}\text { Chi square } \\
(\chi 2)\end{array}$ \\
\hline \multirow{3}{*}{ Adults } & 0.06 & $7.6(6.82-8.81)$ & 5 & 2.04 \\
& 0.12 & $4.34(3.99-4.72)$ & 5 & 1.25 \\
Pupae & 0.25 & $1.16(0.41-1.70)$ & 5 & 3.37 \\
& 0.06 & $3.75(3.06-4.39)$ & 5 & 3.66 \\
& 0.12 & $1.48(0.84-1.95)$ & 5 & 8.05 \\
& 0.25 & $1.04(0.77-1.25)$ & 5 & 9.68 \\
\hline
\end{tabular}

${ }^{\mathrm{a}}$ 95\% lower and upper fiducial limits are shown in parenthesis.

In our observation, $R$. chalepensis essential oil was characterized by typical neurotoxic symptoms including hyperactivity, convulsion, and paralysis with mortality of treated adults. In the pupal stage, we observed other syndromes of intoxication resulting in malformations that can affect the whole body of the insect, and a change in color that becomes darker with the appearance of some necrotic areas (Fig. 1A).

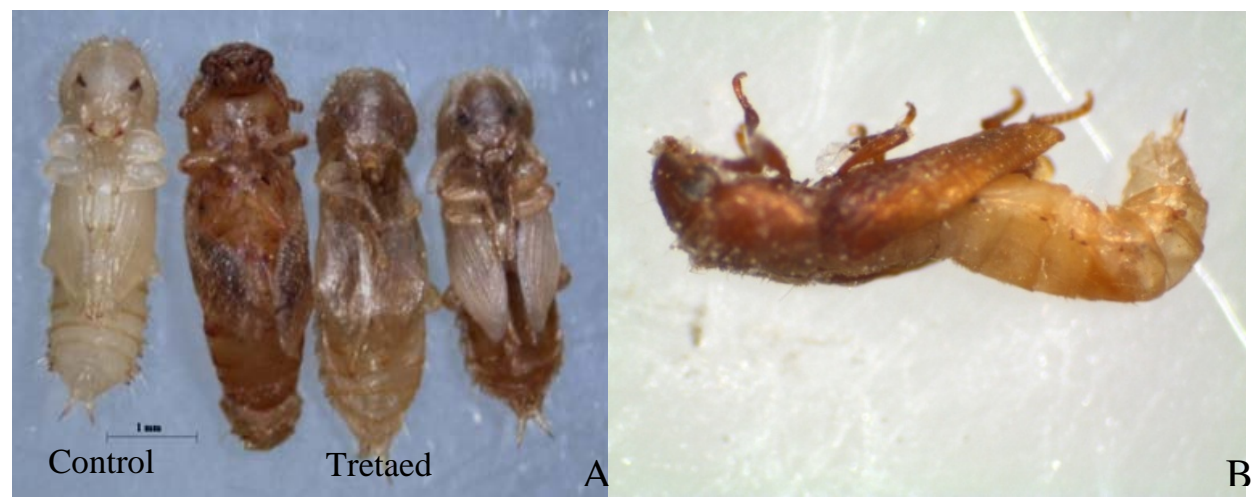

Figure 1. Toxicity effects of $R$. chalepensis essential oils on $T$. confusum pupae (A) and disruption of adult emergence due to the impossibility to reject the old integuments (B). 
We also noted exuviations difficulties due to the impossibility to reject the old integuments causing mortality at the beginning of the adult stage and increased percentage of abnormal insects emerging (Fig. 1B).

\section{Repellency bioassay}

The results of the repellent activity of the essential oils from $R$. chalepensis flowering aerial parts against $T$. confusum adults were presented in Table 4 . The percentage repellency (PR) was determined as function of the oil concentrations and the periods of exposure. As illustrated in table 4, in the binary choice bioassays, the essential oil affects significantly the distribution of insects between the treated and untreated areas and caused acute repellent activity even at the low concentrations tested. The PR values were higher than $50 \%$ at the testing concentrations from the first hour of exposure. The lowest concentration (0.06 $\mu \mathrm{L} / \mathrm{cm}^{2}$ ) led to percentage repellency of $52 \pm 8.36 \%$ at $1 \mathrm{~h}$ after exposure, but it increased to $72 \pm 10.95 \%$ after $4 \mathrm{~h}$. The repellent activity becomes more evident by increasing the concentration of the oil and the maximum PR, independently to the period of exposure, was observed with the highest concentration tested $(0.25$ $\mu \mathrm{L} / \mathrm{cm}^{2}$ ). Indeed, with this latter, repellency was arranged between $78 \pm 14.83$ and $100 \%$ for respectively 1 and $4 \mathrm{~h}$ of exposure (Table 4 ). The analysis of variance with the oil concentrations as classification criteria shows a significant difference among treatments and the $S N K$-test gives heterogeneous groups represented by different letters in Table 4 . Moreover, it was found that PR values are widely correlated to the exposure times and the most effect was noted after 4 $\mathrm{h}$ of exposure with all concentrations applied. The ANOVA analysis indicated that for each tested concentration, significant differences $(P<0.05)$ were obtained between the time periods evaluated. Therefore, the repellent activity of essential oils could be related to the testing concentrations and the exposure duration (Table 4).

Table 4. Percentage repellency (mean $\pm \mathrm{SD}$ ) of $R$. chalepensis essential oils against $T$. confusum adults after various periods of exposure.

\begin{tabular}{lccc}
\hline $\begin{array}{l}\text { Concentrations } \\
\left(\mu \mathrm{L} / \mathrm{cm}^{2}\right)\end{array}$ & $1 \mathrm{~h}$ & $2 \mathrm{~h}$ & $4 \mathrm{~h}$ \\
\hline 0.06 & $52 \pm 8.36^{\mathrm{a}, \mathrm{A}}$ & $66 \pm 5.47^{\mathrm{a}, \mathrm{B}}$ & $72 \pm 10.95^{\mathrm{a}, \mathrm{B}}$ \\
\hline 0.12 & $74 \pm 13.41^{\mathrm{b}, \mathrm{A}}$ & $84 \pm 11.4^{\mathrm{b}, \mathrm{AB}}$ & $98 \pm 4.47^{\mathrm{b}, \mathrm{B}}$ \\
\hline 0.25 & $78 \pm 14.83^{\mathrm{b}, \mathrm{A}}$ & $94 \pm 8.94^{\mathrm{b}, \mathrm{B}}$ & $100 \pm 0^{\mathrm{b}, \mathrm{B}}$ \\
\hline$F$-value & 6.25 & 12.58 & 26.14 \\
\hline$P$-value & 0.014 & 0.001 & $<0.001$ \\
\hline
\end{tabular}

Within column, comparison was made between concentrations (letter in lowercase). Within rows, comparison was made between exposure times for each concentration (letter in uppercase). Means followed by same letter were not statistically different by SNK test at $P<0.05$.

\section{AChE inhibition assay}

$R$. chalepensis essential oils were screened for their AChE inhibitory effects at different concentrations. Results are summarized in Table 5. In control, 
the mean AChE activity remained constant during the experimental period. Values ranged from $1.039 \pm 0.08 \mathrm{nM} / \mathrm{min} / \mathrm{mg}$ proteins at the first day to $1.14 \pm$ $0.06 \mathrm{nM} / \mathrm{min} / \mathrm{mg}$ protein at day 3. However, in the treated series, ANOVA revealed a significant effect ( $P=0.000$ after $72 \mathrm{~h}$ of exposure) of the essential oils on the AChE activity which varied as function of the dose and the duration of treatment. As compared to control, the mean values recorded during the experimental period decreased by raising the concentration of the oil until reaching 40.6 and $50.88 \%$ inhibition after 72 hours of exposure at 0.12 and 0.25 $\mu \mathrm{L} / \mathrm{cm}^{2}$, respectively. Data also indicated that the highest concentration had the greatest inhibitory activity at all the time periods evaluated and there was no significant difference between the two elevated concentrations (Table 5).

Table 5. Effect of $R$. chalepensis essential oils on the activity of acetylcholinesterase (means $\pm \mathrm{SD}, \mathrm{nM} / \mathrm{min} / \mathrm{mg}$ proteins) in surviving insects as function of the concentration and the exposure time.

\begin{tabular}{lccccc}
\hline Exposure & Control & \multicolumn{3}{c}{ EO Concentrations $\left(\mu \mathrm{L} / \mathrm{cm}^{2}\right)$} & $P$-value \\
\cline { 3 - 5 } & & 0.06 & 0.12 & 0.25 & \\
\cline { 3 - 5 } & & $0.93 \pm 0.12^{\mathrm{a}}$ & $0.73 \pm 0.02^{\mathrm{b}}$ & $0.68 \pm 0.05^{\mathrm{b}}$ & 0.003 \\
\hline $24 \mathrm{~h}$ & $1.03 \pm 0.08^{\mathrm{a}}$ & $(89.5)$ & $(70.25)$ & $(65.44)$ & \\
& $(100)$ & $0.92 \pm 0.1^{\mathrm{a}}$ & $0.72 \pm 0.07^{\mathrm{b}}$ & $0.60 \pm 0.04^{\mathrm{b}}$ & 0.001 \\
& $1.01 \pm 0.07^{\mathrm{a}}$ & $(91.08)$ & $(71.28)$ & $(59.4)$ & \\
\hline $78 \mathrm{~h}$ & $(100)$ & $0.64 \pm 0.13^{\mathrm{b}}$ & $0.70 \pm 0.06^{\mathrm{b}}$ & $0.56 \pm 0.05^{\mathrm{b}}$ & $<0.001$ \\
& $1.14 \pm 0.06^{\mathrm{a}}$ & $(56.14)$ & $(61.4)$ & $(49.12)$ & \\
\hline $72 \mathrm{~h}$ & $(100)$ & $(5)$ & &
\end{tabular}

For each exposure time, mean values followed by different letters are significantly different $(P<0.05)$. Values in parentheses indicate per cent change with respect to control taken as $100 \%$.

\section{Glutathione $S$-transferases activity}

As illustrated in table 6, the $R$. chalepensis essential oils caused significant change in the GST activity with a dose-response relationship.

Table 6. Effect of $R$. chalepensis essential oils on the activity of of glutathione $S$ transferases (means $\pm \mathrm{SD}, \mathrm{nM} / \mathrm{min} / \mathrm{mg}$ proteins) in surviving insects as function of the concentration and the exposure time.

\begin{tabular}{llcccc}
\hline \multirow{2}{*}{$\begin{array}{l}\text { Exposure } \\
\text { time }\end{array}$} & Control & \multicolumn{3}{c}{ EO Concentrations $\left(\mu \mathrm{L} / \mathrm{cm}^{2}\right)$} & $\begin{array}{c}P- \\
\text { value }\end{array}$ \\
\cline { 3 - 5 } & & 0.06 & 0.12 & 0.25 & \\
\hline $24 \mathrm{~h}$ & $2.36 \pm 0.38^{\mathrm{a}}$ & $5.34 \pm 0.42^{\mathrm{b}}$ & $7.86 \pm 1.32^{\mathrm{c}}$ & $9.49 \pm 0.94^{\mathrm{d}}$ & $<0.001$ \\
\hline $48 \mathrm{~h}$ & $1.32 \pm 0.22^{\mathrm{a}}$ & $5.77 \pm 0.88^{\mathrm{b}}$ & $8.08 \pm 0.84^{\mathrm{c}}$ & $11.1 \pm 1.27^{\mathrm{d}}$ & $<0.001$ \\
\hline $72 \mathrm{~h}$ & $3.3 \pm 0.24^{\mathrm{a}}$ & $8.01 \pm 1.31^{\mathrm{b}}$ & $9.06 \pm 0.54^{\mathrm{bc}}$ & $10.53 \pm 1.21^{\mathrm{c}}$ & $<0.001$ \\
\hline
\end{tabular}

For each exposure time, mean values followed by different letters are significantly different $(P<0.05)$. 
A significance increase in the GST activity was recorded with the three tested doses starting day 1 of oils application. The enzymatic activity of the treated larvae varied significantly $(P<0.05)$ among themselves and also when compared to the control. The maximum increase, independently to the exposure duration, was observed with the highest concentration tested $\left(0.25 \mu \mathrm{L} / \mathrm{cm}^{2}\right)$. Indeed, the GST activity recorded in the treated group at this concentration is $11.1 \pm 1.27$ and $10.53 \pm 1.21 \mathrm{nM} / \mathrm{min} / \mathrm{mg}$ proteins respectively for 48 and $72 \mathrm{~h}$ of exposure. However, we measured in control insects $1.32 \pm 0.22$ and $3.3 \pm 0.24$ $\mathrm{nM} / \mathrm{min} / \mathrm{mg}$ proteins, respectively to the same exposure times (Table 6).

\section{DISCUSSION}

Some plant extracts and phytochemicals are known to possess insecticidal activity against various insect pests in stored-product and the essential oils extracted from aromatic plants have been widely investigated in this connection. Use of plant oils and its components as pesticide has received much attention of the scientific communities in pest management programme (Chaubey, 2012). In the previous studies, Tapondjou et al. (2005) evaluated contact toxicity of the essential oils extracted from Eucalyptus saligna and Cupressus sempervirens leaves by impregnation on filter paper discs against $T$. confusum. They claimed that these chemicals caused significant mortality with $\mathrm{LC}_{50}$ values of 0.48 and $0.74 \mu \mathrm{L} / \mathrm{cm}^{2}$, respectively for Eucalyptus and Cupressus oils. Similarly, Russo et al. (2015) indicated that essential oils from E. globulus showed interesting insecticidal properties against $T$. confusum adults. Contact toxicity increased according to exposure time and concentration. Indeed, data showed that, at $4 \mathrm{~h}$ exposure, essential oils applied at the lowest concentration $\left(0.5 \mu \mathrm{L} / \mathrm{cm}^{2}\right)$, exhibited the toxicity of $63.33 \%$, while a dose of $0.75 \mu \mathrm{L} / \mathrm{cm}^{2}$ was required to obtain $100 \%$ mortality. However, after $12 \mathrm{~h}$ of exposure, both concentrations killed all tested insects. In their study on the insecticidal activity of the essential oils of three Chrysanthemum species growing in Tunisia (C. coronarium, C. fuscatum, and C. grandiflorum) against T. confusum, Houas et al. (2012) reported that these chemicals caused an antifeeding effect and a high mortality (80\%) of $T$. confusum larvae. The most effective essential oil was obtained from the leaves of C. grandiflorum.

Consulting many papers on this thematic, we can deduce that compared with the other essential oils in the literature, the essential oil of $R$. chalepensis flowering aerial parts possessed stronger contact toxicity against $T$. confusum adults, e.g. essential oils of E. saligna and C. sempervirens $\left(\mathrm{LC}_{95}=1.2\right.$ and 2.42 $\mu \mathrm{L} / \mathrm{cm}^{2}$ calculated for mortality within 3 days of exposure, respectively) (Tapondjou et al., 2005).

In the present study, $R$. chalepensis essential oils have been also evaluated for their repellency. It appears that these compounds repelled $T$. confusum adults significantly even at the lowest concentration used. Similar repellent effects from other plant extracts have been reported. For example, essential oils extracted from E. camaldulensis (Myrtaceae) repelled T. confusum adults in an area 
preference test (Huang et al., 1997). Evodia rutaecarpa (Rutaceae) essential oils also had a repellent effect on $T$. castaneum adults and reduced the growth rate of larvae (Liu and Ho, 1999). Also, Tripathi et al. (1999) reported that fruit oil of Piper retrofractum exhibited high repellency against $T$. castaneum (52, 76 and $90 \%)$ at $0.5,1$ and $2 \%$ concentrations. In the same context, Naseem and Khan (2011), reported in their study on the repellency of the essential oils of $P$. nigrum and $E$. camaldulensis against $T$. castaneum under laboratory conditions that maximum exposure time resulted in maximum repellency of the pest at all the concentrations.

Repellency of $R$. chalepensis essential oils against T. confusum adults appears to be related to the presence of 2-undecanone among the major compounds. In 2007, the arthropod repellent BioUD ${ }^{\circledR}$ (7.75\% 2-undecanone) was registered by the US Environmental Protection Agency for use against mosquitoes and ticks. The active ingredient in BioUD $^{\circledR}$ is the 11 -carbon methyl ketone, 2-undecanone that was originally isolated from the glandular trichomes on the stems and foliage of the wild tomato plant, Lycopersicon hirsutum Dunal f. glabratum (Farrar and Kennedy, 1987). Resistance of L. hirsutum f. glabratum to insect herbivory is due in part to the presence of 2-undecanone (Kennedy, 2003). Witting-Bissinger et al. (2008) showed that BioUD ${ }^{\circledR}$ was an efficacious repellent against Dermacentor variabilis (Arachnida: Ixodidae) in laboratory studies on treated human skin, cloth, and filter paper. Additional research was conducted by Witting-Bissinger et al. (2009) to evaluate the repellency of BioUD $^{\circledR}$ against three tick species (Acari: Ixodidae): Amblyomma americanum, D. variabilis, and Ixodes scapularis, important in disease pathogen transmission and to determine quantitative differences with DEET ( $N, N$ diethyl-m-toluamide) (98.11\%), the most extensively used active ingredient in commercial arthropod repellents. A two-choice bioassay between repellent-treated and untreated filter paper surfaces was used under controlled laboratory conditions. The results showed that BioUD ${ }^{\circledR}$ is at least 2-4 times more active as a repellent than DEET against the three species of ixodid ticks.

In a second series of experiments, the essential oils of $R$. chalepensis were investigated on the activities of acetylcholinesterase (AChE) and glutathione $S$ transferases (GSTs). Data showed that the compound induced GSTs and reduced the activity of AChE. The GSTs are known to play a central role in the detoxification of both endogenous and xenobiotic compounds and are involved in intracellular transport and various biosynthetic pathways (Che-Mendoza et al. 2009). They play an important role in insecticide resistance and are implicated in the metabolism of organophosphorus and organochlorine compounds (Fang, 2012). Other xenobiotics such as plant secondary metabolites induce GST activity in phytophagous insects, and similarly in predators that feed on these herbivores (Vanhaelen et al. 2004, Acheuk et al., 2018). AchE has a key role in neurotransmission by hydrolyzing the neurotransmitter acetylcholine in cholinergic synapses of the nervous system and is the target site of several neurotoxic insecticides. The essential oils of $R$. chalepensis exhibited a 
neurotoxic action in T. confusum resulting in convulsions, lack of mechanical coordination and tremors. Several previous studies reported that rapid action of essential oils against insect pests is an indicative of neurotoxic actions. Bessette et al. (2013) noted that in direct contact, essential oils may penetrate via insect's cuticle and contact the nerve endings in the invertebrate pest's trachea, and cause neurotoxic activity and more rapid death. The neurotoxic modes of action on insects are mainly related to AChE levels and several reports have demonstrated the interference of essential oils or its constituents with AChE enzyme activity in insects (Yeom et al. 2013). However, it is suspected that, in addition to AChE inhibition, the monoterpenes may act on other vulnerable sites (e.g. cytochrome P450-dependent monooxygenases) (Rajendran and Sriranjini, 2008). In fumigant toxicity tests with monoterpenes (limonene, linalool, menthol, menthone, $\alpha$ pinene, $\beta$-pinene) against Sitophilus oryzae adults, Lee et al. (2001) did not find a direct correlation between insect toxicity and AChE inhibition.

As we have shown previously, $R$. chalepensis essential oils induced GSTs activity in T. confusum. Similarly, Vanhaelen et al. (2004) showed that Brassicacea secondary metabolites induced GST activity in Myzus persicae and several Lepidopteran species such as Heliothis virescens and Trichoplusia ni. By treating Artemisia annua extracts on Eurygaster integriceps adults, Zibaee and Bandani (2010) also reported that activity level of GST in $24 \mathrm{~h}$ post-treatment increased significantly.

\section{CONCLUSIONS}

The development of natural insecticides would help to decrease the negative impact of synthetic insecticides, such as residues, resistance, and environmental pollution. In the present study, $R$. chalepensis essential oils showed strong contact toxicity against $T$. confusum. Based on these findings, it can be suggested that essential oils of plant origin could have greater potential in future on the basis of their efficacy, economic value and use in large-scale storage.

\section{REFERENCES}

Abdellaoui, K., Ben Halima-Kamel, M., Acheuk, F., Soltani, N., Aribi, N., Ben Hamouda M.H. (2013). Biochemical and histological effects of gibberellic acid on Locusta migratoria migratoria fifth instar larvae. Pesticide Biochemistry and Physiology, 107, 32-37.

Abdellaoui, K., Ben Halima-Kamel, M., Acheuk, F., Soltani, N., Aribi, N., Ben Hamouda, M.H. (2015). Effects of gibberellic acid on ovarian biochemical composition and ecdysteroid amounts in the migratory locust Locusta migratoria (Orthoptera, Acrididae). International Journal of Pest Management, doi: 10.1080/09670874.2014.995746.

Acheuk, F., Lakhdhari, W., Dahliz, A., Abdellaoui, K., Moukadem, M., Allili, S. (2018). Toxicity, acethylcolinesterase and glutathione S-transferase effects of Halocnemum stobilaceum crude extract against Tribolium castaneum, Agriculture \& Forestry, 64 (1), 23-33. 
Amason, J.T., Johns, T., Hebda, R. (1981). Use of plants for food and medicine by native peoples of Canada. Canadian Journal of Botany, 59, 2189-2375.

Bakkali, F., Averbeck, S., Averbeck, D., Idaomar, M. (2008). Biological effects of essential oils e a review. Food and Chemical Toxicology, 46, 446-475.

Bessette, S., Lindsa, A., Enan, E. (2013). Pesticidal compositions containing rosemary oil and wintergreen oil. US Patent. US 20130142893 A1.

Bradford, M.M. (1976). A rapid and sensitive method for the quantitation of microgram quantities of protein utilizing the principle of protein dye binding. Analytical biochemistry, 72, 248-254.

Butler, J.H., Rodriguez, J.M. (1996). Methyl bromide in the atmosphere. In: Bell, C.H., Price, N., Chakrabarti, B. (Eds.), The Methyl Bromide Issue, vol. 1. Wiley, West Sussex, England, pp. 27-90.

Chaubey, M.K. (2012). Acute, lethal and synergistic effects of some terpenes against Tribolium castaneum Herbst (Coleoptera: Tenebrionidae). Ecologica balkanica, 4, 53-62.

Che-Mendoza, A., Penilla, R.P., Rodriguez, D.A. (2009). Insecticide resistance and glutathione S-transferases in mosquitoes: A review. African Journal of Biotechnology, 8, 1386-1397.

Collins, P.J., Daglish, G.J., Pavic, H., Kopittke, R.A. (2005). Response of mixed-age cultures of phosphine-resistant and susceptible strains of lesser grain borer, Rhyzopertha dominica, to phosphine at a range of concentrations and exposure periods. Journal of Stored Products Research, 41, 373-385.

Ellman, G.L., Courtney, K.D., Andres, J.V., Featherstone, R.M. (1961). A new and rapid colorimetric determination of acetylcholinesterase activity. Biochemical Pharmacology, 7, 88-95.

Fang, S.M. (2012). Insect glutathione S-transferase: a review of comparative genomic studies and response to xenobiotics. Bulletin of Insectology, 65, 265-271.

Farrar, R., Kennedy, G.G. (1987). 2-Undecanone, a constituent of the glandular trichomes of Lycopersicon hirsutum f. glabratum: Effects on Heliothis zea and Manduca sexta growth and survival. Entomologia Experimentalis et Applicata, 43, 17-23.

Finney, D.J. (1971). Probit analysis, 3rd ed. Cambridge University, London, UK.

Habig, W. H., Pabst, M. J. and Jacoby, W. B. 1974. Glutathione S-transferases: the first enzymatic step in mercapturic acid formation. Journal of Biological Chemistry, 249, 7130-7139.

Haouas, D., Cioni, P.L., Ben Halima-Kamel, M., Flamini, G., Ben Hamouda, M.H. (2012). Chemical composition and bioactivities of three Chrysanthemum essential oils against Tribolium confusum (du Val) (Coleoptera: Tenebrionidae). Journal of Pest Science, 85, 367-379.

Ho, S.H., Koh, L., Ma, Y., Huang, Y., Sim, K.Y. (1996). The oil of garlic, Allium sativum L. (Amaryllidaceae), as a potential grain protectant against Tribolium castaneum (Herbst) and Sitophilus zeamaiz Mostch. Postharvest Biology and Technology, 9, 41-48.

Huang, Y., Tan, J.M., Kini, R.M., Ho, S.H. (1997). Toxic and antifeedant activities of nutmeg oil against Tribolium castaneum (Herbst) and Sitophilus zeamais Motsch. Journal of Stored Products Research, 33, 289-298.

Isman, M.B. (2000). Plant essential oils for pest and disease management. Crop Protection, 19, 603-608.

Jarraya, A. (2003). Principaux nuisibles des plantes cultivées et des denrées stockées en Afrique du Nord: leur biologie, leurs ennemis naturels, leurs dégâts et leur contrôle. Maghreb Editions, Tunisia. 415 pp. 
Kennedy, G.G. (2003). Tomato, pests, parasitoids, and predators: tritrophic interactions involving the genus Lycopersicon. Annual Review of Entomology, 48, 51-72.

Lee, S.E., Lee, B.H., Choi, W.S., Park, B.S., Kim, J.G., Campbell, B.C. (2001). Fumigant toxicity of volatile natural products from Korean spices and medicinal plants towards the rice weevil, Sitophilus oryzae (L). Pest Management Science, 57, 548553.

Liu, Z.L., Ho, S.H. (1999). Bioactivity of the essential oil extracted from Evodia rutaecarpa Hook f. et Thomas against the grain storage insects Sitophilus zeamais Motsch and Tribolium castaneum (Herbst). Journal of Stored Products Research, 35, 317-328.

Liu, X.C., Yang, K., Wang, S.Y., Wang, X.G., Liu, Z.L., Cheng, J. (2013). Composition and insecticidal activity of the essential oil of Pelargonium hortorum flowering aerial parts from China against two grain storage insects. Journal of medicinal plant research, 4, 3263-3268.

MBTOC. (1998). Methyl Bromide Technical Options Committee: Assessment of alternatives to methyl bromide. Nairobi, Kenya, United Nations Environment Programme, Ozone Secretariat.

Naseem, M.T., Khan, R.R. (2011). Comparison of repellency of essential oils against red flour beetle Tribolium castaneum Herbst (Coleoptera: Tenebrionidae). Journal of Stored Products Research, 2, 131-134.

Nerio, L.S., Olivero-Verbel, J., Stashenko, E.E. (2009). Repellent activity of essential oils from seven aromatic plants grown in Colombia against Sitophilus zeamais Motschulsky (Coleoptera). Journal of Stored Products Research, 45, 212-214.

Park, D.S., Peterson, C., Zhao, S., Coats, J. R. (2004). Fumigation toxicity of volatile natural and synthetic cyanohydrins to stored-product pests and activity as soil fumigants. Pest Management. Science, 60, 833-838.

Pimentel, M.A.G., Faroni, L.R.D.A., Guedes R.N.C., Sousa, A.H., Tótola, M.R. (2009). Phosphine resistance in Brazilian populations of Sitophilus zeamais Motschulsky (Coleoptera: Curculionidae). Journal of Stored Products Research, 45: 71-74.

Rajendran, S., Sriranjini, V. (2008). Plant products as fumigants for stored-product insect control. Journal of Stored Products Research, 44, 126-135.

Russo, S., Cabrera, N., Chludil, H., Yaber-Grass, M., Leicach, S. (2015). Insecticidal activity of young and mature leaves essential oil from Eucalyptus globulus Labill. against Tribolium confusum Jacquelin du Val (Coleoptera: Tenebrionidae). Chilean Journal of Agricultural Research, 75, 375-379.

Sahaf, B.Z., Moharramipour, S., Meshkatalsadat, M.H. (2008). Fumigant toxicity of essential oil from Vitex pseudo-negundo against Tribolium castaneum (Herbst) and Sitophilus oryzae (L.). Journal of Asia-Pacific Entomology, 11, 175-179.

Suthisut, D., Fields, P.G., Chandrapatya, A. (2011). Fumigant toxicity of essential oils from three Thai plants (Zingiberaceae) and their major compounds against Sitophilus zeamais, Tribolium castaneum and two parasitoids. Journal of Stored Products Research, 47, 222-230.

Tapondjoua, A.L., Adlerb, C., Fontem, D.A, Boudaa, H., Reichmuthb, C. (2005). Bioactivities of cymol and essential oils of Cupressus sempervirens and Eucalyptus saligna against Sitophilus zeamais Motschulsky and Tribolium confusum du Val. Journal of Stored Products Research, 41, 91-102.

Tripathi, A.K., Prajapati, V., Gupta, R., Kumar, S. (1999). Herbal material for the insect pest management in stored grain under tropical conditions. Journal of Medicinal and Aromatic plant Sciences, 2, 408-420. 
Vanhaelen, N., Francis, F., Haubruge, E. (2004). Purification and characterization of glutathione S-transferases from two syrphid flies (Syrphus ribesii and Myathropa florea). Comparative Biochemistry \& Physiology B, 137, 95-100.

Witting-Bissinger, B.E., Stumpf, C.F., Donohue, K.V., Apperson, C.S., Roe, R.M. (2008). Novel arthropod repellent, BioUD, is an efficacious alternative to DEET. Journal of Medical Entomology, 45, 891-898.

Witting-Bissinger, B.E., Apperson, C.S., Sonenshine, D.E., Waston, D.W., Roe, R.M. (2009). Efficacy of the new repellent BioUD ${ }^{\circledR}$ against three species of ixodid ticks. Experimental and Applied Acarology, 48, 239-250.

Yeom, H.J., Jaesoon, J., Kim, S.W., Park, I.K. (2013). Fumigant and contact toxicity of Myrtaceae plant essential oils and blends of their constituents against adults of German cockroach (Blattella germanica) and their acetylcholinesterase inhibitory activity. Pesticide Biochemistry and Physiology, 107, 200-206.

Zhang, J.S., Zhao, N.N., Liu, Q.Z., Liu, Z.L., Du, S.S., Zhou, L.G.,Deng, Z.W. (2011). Repellent constituents of essential oil of Cymbopogon distans aerial parts against two stored-product insects. Journal of Agricultural and Food Chemistry, 59, 99109915.

Zibaee, A., Bandani, A.R. (2010). Effects of Artemisia annua L. (Asteracea) on digestive enzymes profiles and cellular immune reactions of sunn pest, Eurygaster integriceps (Heteroptera: Scutellaridae), against Beauvaria bassiana. Bulletin of entomological research, 100, 185-196. 